\title{
Editorial
}

\section{Modernidade líquida, trabalho colaborativo e o saber das revistas}

Nos tempos líquidos nos quais vivemos, segundo Zigmunt Bauman, tudo tem duração curta, vida efêmera e volátil. Com a temperatura é elevada, não há condições dos líquidos se solidificarem. As pessoas se sentem inseguras, há instabilidade e perda de confiança e, na ausência de autoridades confiáveis, surgem os exemplos líderes, professores e outros.

A cada ano que passa as tecnologias evoluem. Os dispositivos móveis têm cada vez mais funções, tornam-se menores e com mais capacidade. As pessoas são bombardeadas por informação e passam a saber menos de mais coisas. Menos porque a profundidade que os dispositivos móveis fornecem é pequena comparada aos livros e periódicos.

Em paralelo há outras tendências, entre as quais uma é a da especialização na sociedade com pessoas seguindo carreiras humanas, outras seguindo as ciências, outras profissões tecnológicas, mais ainda as pessoas das ciências sociais aplicadas, muitas outras seguindo as ciências da saúde e aí vai indo para as especializações dentro de uma grande área do saber.

Nos tempos atuais com a tendência das especializações, muitas pessoas perdem a noção sistêmica do todo e estão mais preocupadas com suas especialidades, gerando complexidades e o pensamento complexo como considera Edgar Morin. Este ainda sugere que para superar essas dificuldades torna-se interessante cultivar os valores entre os quais o amor ao próximo e o respeito às diferenças.

Uma das formas de se fazer um movimento contrário, ou seja, que vá de encontro às dificuldades é por meio da multidisciplinaridade com trabalho colaborativo. Por meio dessa, torna-se possível quebrar as barreiras disciplinares entre diferentes ciências e saberes e buscar com respeito e colaboração, um trabalho conjunto com objetivo comum.

Tendo em vista a difícil tarefa de superar as barreiras das disciplinas, a tendência a individualidade e, sabemos que para fazer frente aos tempos nos quais vivemos, torna-se necessário o esforço e a dedicação de todos, mas, trabalhando com a flexibilidade e tolerância para alcançar objetivos comuns e superando as barreiras e diferenças.

A revista baseando-se nos conceitos expostos, começou multidisciplinar e é uma 
grande honra trabalhar com as diferenças e os saberes diversos considerando que após um grande período de divergência, podemos encontrar pontos comuns e buscar agendas positivas e convergências que podem nos levar a situações melhores que as dos tempos atuais.

Nosso objetivo é disseminar o saber na sociedade uma vez que acreditamos que por meio dele é possível se alcançar uma condição de vida melhor para todos por meio do letramento e do conhecimento. Pedimos que nos continuem ajudando a disseminar o saber sobre a revista e seu conteúdo e desta forma, vamos juntos tentando superar as dificuldades dos tempos atuais.

Estamos em evolução, no sentido de melhorar quantitativamente e qualitativamente, tentando superar nossos limites para servir à sociedade na qual estamos inseridos, para tentar atender melhor aos leitores, autores e toda comunidade que se integra de alguma forma à revista Research, Society and Development e desta forma, agradecemos a todo apoio e a todos desse comunidade seja local, nacional ou internacionalmente: apresentamos nossa gratidão a todos sem exceção.

Desejamos a todos, boa leitura, construção do saber, superação e, sucesso sempre, seja ele como nos tempos antigos de solidez, dos tempos atuais líquidos ou tempos futuros que quem sabe sejam gasosos, plasmáticos, energéticos, virtuais ou, de outra natureza que ainda nem imaginamos como poderia ser.

Seja como for, as revistas cientificas trazem uma situação mais atual e atualizada do saber em relação aos livros, sejam eles em papel ou e-books e desta forma por meio do saber dos periódicos, podemos nos preparar, desenvolvendo habilidades e competências para fazer frente aos tempos que vierem e. para que possamos juntos trabalhar colaborativamente ao favor de buscar a resolução para os problemas da sociedade.

\section{Dr. Ricardo Shitsuka}

Editor 